\title{
Behavioral Geography: As a New Trend in Medical Geography Studies
}

\author{
Mohamed Nour Eldin Elsabawy \\ Professor of Human and Medical Geography, \\ Minia University, Egypt
}

\section{Doi:10.5901/mjss.2013.v4n7p75}

\begin{abstract}
This paper aims to study another dimensions in behavioral geography related to medical geography branch as a subfield in geographic discipline. Environmental health and disease of human kind is focus of this study, we can see this aspects clear through behavior of utilization building roofs in multi unhealthy using, as investment without care about environmental health care. Or through personal considerations such as nutrition behavior, treatment behavior, and health awareness. Child abuse is in the focus of this study too because it has relation to ethics and to determine areal differentiations between many regions and laws control these phenomena.
\end{abstract}

Keywords: Geography, Behavioral, cognitive, Medical geography.

\section{Introduction}

Behavioral Geography as important new themes in human geography were recognized in the 1960s, to examines human behavior using a disaggregate approach, deals with the study of cognitive processes with its response to the environment, through behaviorism(1), underlying spatial reasoning, decision making, It was draws early from behaviorist works such as Tolman's concepts of "cognitive or mental maps.

In addition, behavioral geography is an ideology/approach that makes use of the methods and assumptions of behaviorism to determine the cognitive processes involved in an individual's perception of, and/or response and reaction to their environment. The approach adopted in behavioral geography is closely related to that of psychology but draws on research findings from a multitude of other attitudes and disciplines including Customs, habits, heritage, health, economics, sociology, anthropology, transportation planning, and many human and physical aspects.

Some geographers studies behavioral geography through recognition of spatial dimensions of sites and relationship with some skills and experience, mental map is one of this experiences and recognition, realize and understanding relationship between human and his environment.

\section{Objective}

This paper aims to study another dimensions in behavioral geography related to medical geography branch as a subfield in geographic discipline. Environmental health and disease of human kind is focus of this study,

${ }^{1}$ Because of the name it is often assumed to have its roots in behaviorism. While some behavioral geographers clearly have roots in behaviorism. See Norton, W. (2001). Initiating an affair human geography and behavior analysis. The Behavior Analyst Today, 2 (4), 283-290.. Behavioral geographers focus on the cognitive processes underlying spatial reasoning, decision making, and behavior. More behaviorally oriented geographers are materialists and look at the role of basic learning processes and how they influence the landscape patterns or even group identity. See Norton, W. (1997). Human geography and behavior analysis: An application of behavior analysis to the evolution of human landscapes. The Psychological Record, 47, 439-460. 
we can see this aspects clear through behavior of utilization building roofs in multi unhealthy using, as investment without care about environmental health care. Or through personal considerations such as nutrition behavior, treatment behavior, and health awareness. Child abuse is in the focus of this study too because it has relation to ethics and to determine areal differentiations between many regions and laws control these phenomena.

\section{Methods and Materials}

This study depends upon many aspects of Human behavior, takes many shapes covers:-

1. Behavior of living (Unhealthy roof using)

2. Behavior of treatment

3. Nutritional behavior

4. Environmental health behavior

5. Street Peddlers as a behavior

6. Child abuse

These relations through field work study in many places in Egypt, from the villages of Kafr Elsheikh in the north of delta, to Minia in the middle Egypt. Pictures is important tool to give facts directly without exaggeration, also maps\&diagrams is another tool clarify the areal differentiations, and statistical analysis give results more confidence and subjectivity.

\section{Results and discussions}

\subsection{Unhealthy roof using}

The study of exploitation of Building roofs and its effects in ecology health considered in the focus of study in 2006 in Egypt (1), the results of this study confirmed that there are many factors behind this exploitation, some of them physical concerned with geological structure, weather and seasonal variations, site and situation and patterns of agricultural activity, and some of them related to life style and economic circumstances which push many peoples to save every second hand things in the roofs of their buildings as a type of " poverty economics" one of editors called this phenomena "second hand servitude", these aspects of using is harmful because it is allow to rodents and insects for spread and contaminated the environment. In rural areas agriculture activity allow for cultivating some kinds of plants like rice cotton and corn, farmers saving their products and by products such as stem of this plants on the roofs of buildings in order to protect it from high temperature in summer, and cold weather in winter, and to use these by products as a biogas stove tool or as a food of animals, (see figure 1) these things create a good environment to rodents and insects living and growing. Many people in the villages either in valley or delta saving droppings of animals in the roofs too in order to use it as a biogas for locally primary stove, called "Canoon" (see figuure 2) in spite this activity is related to life style and low income for poor peoples, but it is consider as an behavior effecting in the environmental health and doing bad pollution in the rural and urban places they use this tools. 


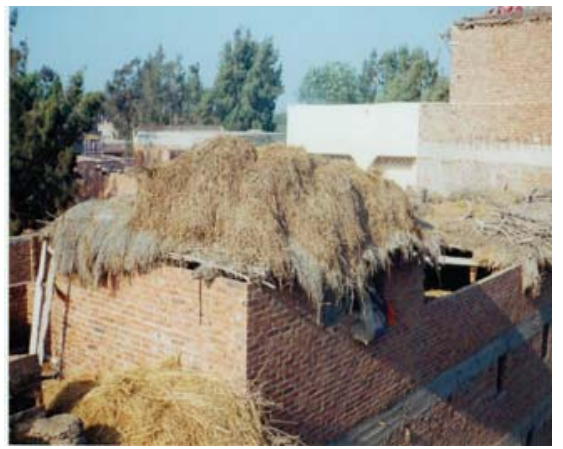

Figure 1: Saving straw or hay on the roofs of rural buildings give the chance to rats and insects spread Example from Gamagmoun Village,Desuck district, KafrElsheikh Governorate,May 2006.

The recommendations of this study suggested that the government must following this kind of exploitation and encouragement of peoples and enactment to save the environment and transfer this roofs to be as a cities lung, through planting some kinds of flowers and aromatic plants.

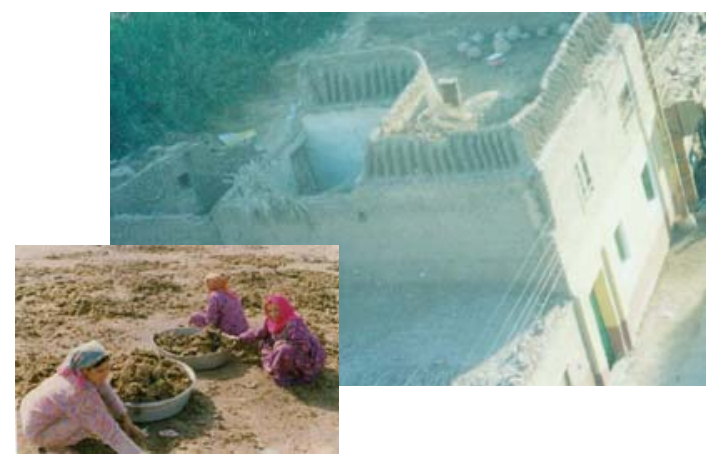

Figure 2: Behavior of Saving the cattle disposal on the house roof for biogas stove, may pollute the environment and spread the harmful insects.

Example from Talla village, Minia District, Minia Governorate, April 2006

\subsection{Behavior of treatment}

The study of sick people behavior in treatment from diseases who they suffer from, is considered as one the interests of the study of medical geography (2). Many peoples in rural areas prefer the ethnomedicine, and medical pluralism. And hepalists and diviners Through the study in 1995 about Behavioral dimension in the study of Medical Geography, with applied study in the Egyptian village "Toukh Elkhail" Minia, province, the percentage of population sample depends on traditional medicine was $71.2 \%$, over than 95.5 from this percentage used medicinal and aromatic plants in treatment, like boiled green mint to treat headache , Caraway and anise for diarrhea, Cumin and mint for constipation, and boiled barley for kidney pain, about 12.5\% from the sample drink the Guava paper for cough (Elsabawy,M.N., 2004.P:26) .

Behavioral geographers analyze data on the behavior of individual people, recognizing that individuals vary from each other. A key tenet of behavioral geography holds that models of human activity and interaction can be improved by incorporating more realistic assumptions about human behavior. For example, behavioral geographers agree with other human geographers that distance (or related factors such 
as travel time or effort) is an important determinant of human activity, but they maintain that it is subjective rather than objective distance that is typically important. And because different people's beliefs about distances may vary considerably from one another and from objective distance, spatial activities will be more variable and less optimal than non behavioral models predict.

The study of journey to treatment in the sample of patients coming to some hospitals in Minia City , Dessuck city Kafr Elshekh governorate, confirmed that there are negative relationship between distance and density of population entered to hospital, wherever increase the number of peoples coming to hospital when distance is short, this is according to the least effort principle, and distance decay theory which means increase the value of phenomena with near of core

\subsection{Nutritional behavior.}

Nutritional behavior playing a great role in the health of human body, many peoples didn't take their meals on time or as a balance diet, calories intake for reasons related to behavior or poverty is less than normal averages, The main meal of many peoples in rural areas in the night, because they spent all the day in the field to cultivate their lands. So they are eating meats, rice, vegetables in the night, Even children didn't obtain their needs from calories they need in the stage of building their bodies. In applied study of calories intake among high schools in Egypt, the results confirmed that the child between ages 12- 15 years old was abnormal in the weight and lengths comparing with standard scale.

Nutritional behavior in the type and distribute of bread is important too, because the methods of preparing bread and distributing often not healthy, and it is different in the Upper Egypt than any another place in Delta, in Upper Egypt they prepare more than 10 types of bread, sunny bread, stone bread, Fayesh, Keshk, Pettaw, Wheat bread, Corn bread, Barely bread, Menatat, and fenugreek bread, every type is different in service, component and value. Figure 3

Related to this point too the distribution of food in the family is liable to Hierarchal system, in the big families, there is Gender gap in the food distribution, so male is eating first, and then remaining food push to family, the oldest one usually is father is take a big amount specially from meat or chicken, and then who is younger than him and so on., in spite this system is not acceptable as ethics and not acceptable too in the health, because child in the ten ages needs more calories to build their bodies than elder. But this is the system of nutritional behaviour

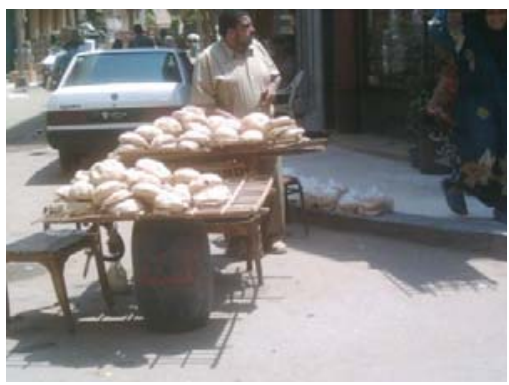

Figure 3: Bread in the streets without care of clean

\subsection{Environmental health behavior}

The results of study about Environmental health Awareness Scale:A proposed model for Egypt as a developing country show that there are differences in the environmental health awareness between the population in rural areas of each district in the Governorate, these differences not only between rural areas, 
but also between urban cities. Many factors behind these differences between people who living in rural or urban. The main reason of these differences depending on the socioeconomic and educational level, and occupation, certainly the high level in education is playing a great role in the increasing level of environmental health awareness between people, correlation coefficient between the degree of environmental health awareness and the level of illiteracy confirmed that there is significant correlation whereas environmental health awareness increased with increase of education level. It is suitable scale for Egypt, as a developing country.

Table 1 : Environmental health awareness scale between sample of rural and urban population in Minia districts 2010.

\begin{tabular}{|c|c|c|c|c|c|c|}
\hline Districts & $\begin{array}{c}\text { Degree of } \\
\text { environmental } \\
\text { health } \\
\text { awareness in } \\
\text { rural }\end{array}$ & $\begin{array}{c}\text { Degree of } \\
\text { environmenta } \\
\text { I health } \\
\text { awareness in } \\
\text { urban }\end{array}$ & $\begin{array}{c}\text { Percent of } \\
\text { Illiteracy in } \\
\text { rural }\end{array}$ & $\begin{array}{c}\text { Percent of } \\
\text { Illiteracy in } \\
\text { urban }\end{array}$ & $\begin{array}{c}\text { Percent of } \\
\text { agricultural } \\
\text { activity } \\
\text { workers in } \\
\text { rural }\end{array}$ & $\begin{array}{c}\text { Percent of } \\
\text { agricultural } \\
\text { activity } \\
\text { workers in } \\
\text { urban }\end{array}$ \\
\hline El Edwa & 46.53 & 48.4 & 34.2 & 27.3 & 17.5 & 3.1 \\
\hline BiniMazar & 48.5 & 52.6 & 38.3 & 25.8 & 18.1 & 2.8 \\
\hline Samalut & 65 & 58 & 38.8 & 23.4 & 17.9 & 2.3 \\
\hline abokerkas & 50 & 54 & 39.3 & 23.2 & 18.1 & 2.3 \\
\hline Dermawas & 43.1 & 58 & 38.8 & 26.7 & 14.2 & 2.1 \\
\hline Maghagha & 63.9 & 65.2 & 39.6 & 23.2 & 18.1 & 3.1 \\
\hline Mattay & 50 & 54.6 & 37.8 & 22.6 & 18.8 & 2.6 \\
\hline Minia & 46.8 & 58 & 31.2 & 11.6 & 15.4 & 1.1 \\
\hline Malawi & 44.7 & 66 & 36.2 & 21.5 & 14.5 & 2.4 \\
\hline
\end{tabular}

Environmental health scale between
sample of rural population in Minia districts

Environmental health scale between sample of rural population in Minia districts sample of urban population in Minia districts 2010 2010
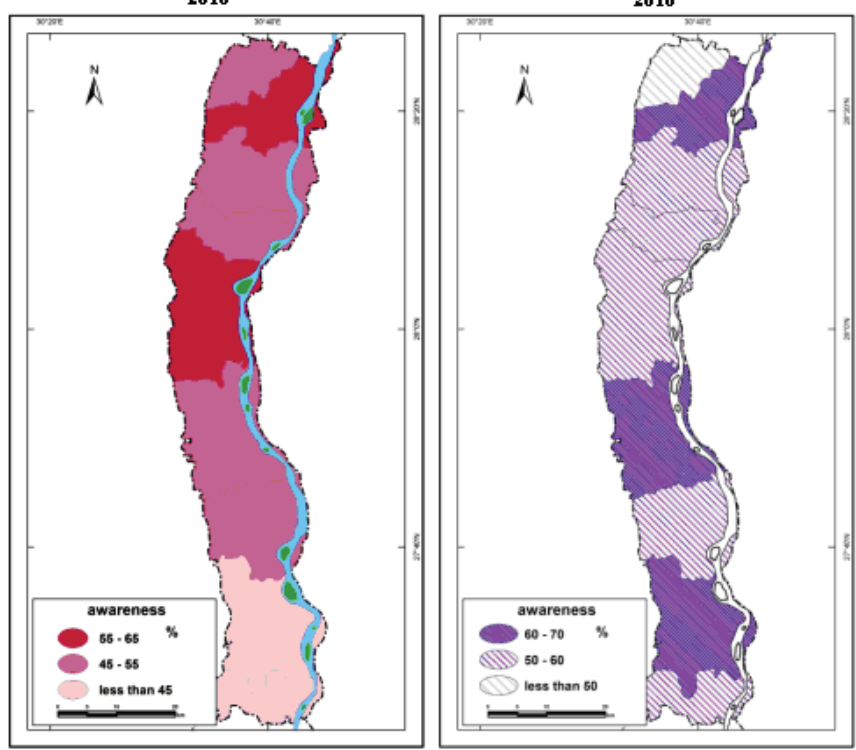

Figure 4: Environmental health awreness between rural and Urban places in Minia Districts, Egypt 


\subsection{Street Peddlers as a behavior}

Researcher study Beans Peddlers in Alexandria City as a one aspect of behavioral geography concerned with Economic and social dimension for population sample who are suffering from poverty and privation in their home site; searching for food and change of their living and life style in new places far from their home country about more than $400 \mathrm{~km}$.

The Researcher noticed during his walking in Alexandria City streets, especially in the morning and afternoon, that many people are gathering around a poor woody car which from a special shape to include many oil bottles, salty things, vinegar, amounts of onions and other unknown things in the shelves. Looking inside this car, you can find big bottle of beans. (see figure ) where the seller, who is not an Alexandrian man, is standing on front of this car. It spreads in every corner in Alexandria city from Alagamy suburb in the west to Abokeer in the east. Sellers are distributed in every place. Every one has a place which is far from the other one by hundred meters at least. It is considered a geographic distribution that include geographical theories (i.g) "Central Place Theory", neighborhood analysis, or gravity model, and without any support from administration in choosing their places or supervising for their survive.

All people who work in this business are from one main village and some other tributary villages in Minia governorate in the middle Egypt. Their need to social nearness, and feeling with safety is one of the grounds to live together in new community perform the top of urban hierarchy which is different than their small and poor villages in Middle Egypt. Behavioral dimension too is the target of studying, why these people choose this kind of business?, and for popular people who is eating this kind of foods in the streets, standing on front of open cars prone to pollution, dust and flies on roadway. This behavior goes against the health specifications through offering food in plastic plates and second hand materials without any kind of health care.

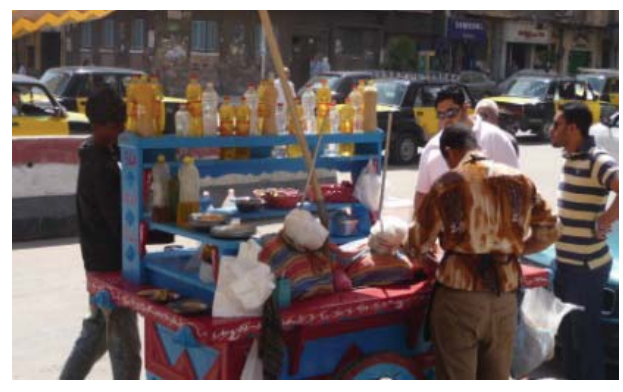

Figure 5: Peddler poor woody car in Alexandria city (Sedy Beshr up to Abd-Elnasser subway street ( 4 july 2011)

Those sellers offer fast food beans meals with fresh vegetables in plastic or stainless plates for people who are hurrying up to go to their work early in the morning. All of them didn't care about health specifications and they didn't observe or care about the case of food served to them from peddler's sellers. This scene reminds me of other peddler's sellers. But this time was in New York City in July 1992 when I was in Manhattan, where many Egyptians spreading peddlers in new York city streets, but they offers another kind of food for American peoples like hotdog, hamburger, because American people didn't do these works, so they left it to those who come from the third world. But with the difference between the case of this car, and the woody beans car in Alexandria City. This is the main reason that summons to study this topic which act behavioral living and a phenomenon changed to be daily custom for category of society from poor and popular people which the plate of beans represents the main meal. The problem in this behavior is the type of hepatitis $A$ is related to careless and unclean environment, where flies and insects spread, in addition to the prevalence of 
prowling dealers in the most of urban streets, who cook some fast foods like beans, liver, brain and bowel animals. Many people like to eat these fast foods which are prepared by some unhealthy and unlearned people in the streets caravan without healthy censorship from the health legislation. This is the first furtive door to infect them with hepatitis A.

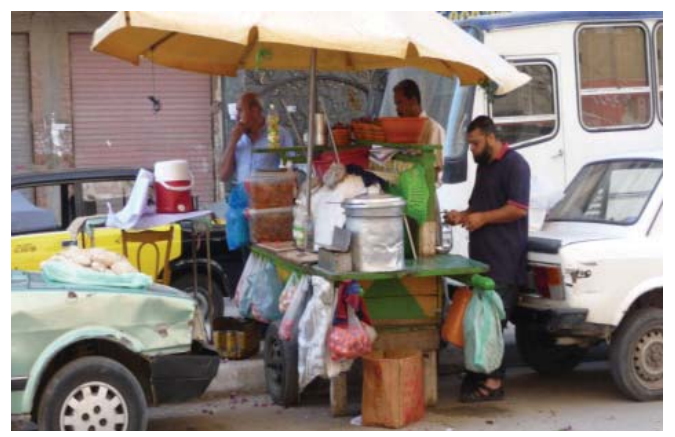

Figure 6: Unclean meal can spread infectious diseases like Hepatitis A,and this is the responsibility of ministry of health

In spite of the facetiousness of this topic study, but it represents an important behavioral phenomenon that spreads in many urban sites in Egypt, for category of peddlers or prowlers offer their fast foods to many poor people from workers, and small officials who find delight in this bean meal, because of their social level can't allow them to live well-being to have to another fast foods like hamburger, livers, and beef. Therefore, their salaries are not enough more to do that.

\subsection{Child Abuse}

The study of Child abuse in geographical view was in the focus of study by researcher in the beginning of this century 2003, when he is follow the aspects of child abuse through the world and field work studies in some places in Egypt to determine areal differentiations and spatial dimensions in the exploitation of children in the farms, factories, different works, and in the home service. Egypt was an early signatory to the Convention on the Rights of the Child and one of the six initiators of the first World Summit for Children.

The child abuse takes many aspects, some of them related to physical abuse, including body punishment, sexual abuse, and psychological abuse including deprivation from education, expenses, health care needs, and emotional deprivation, every aspect can lead child to be criminal. Areal differentiations seems to be more clear between rural and urban, and in the close families more than open families, and between agriculture societies compare with industrial societies. The most bad aspect of this neglect is Street children phenomena, this problem is not in Egypt only, but many cities in the world suffering from it, it is consider the most ethical problem meet civilized countries or political systems. In Brazil it considers the most problem in Reo de Janero and Brasília, there are more than 1.5 million child staying in the streets without shelter In Cairo too there are more than one million child and girl living in the pipes of waters, drainages, tires of cars and in the blighted areas, they distribute all kind of drugs and taking drug injections in the streets, many of them suffer from hepatitis and infectious diseases and they are spread these diseases to another peoples 

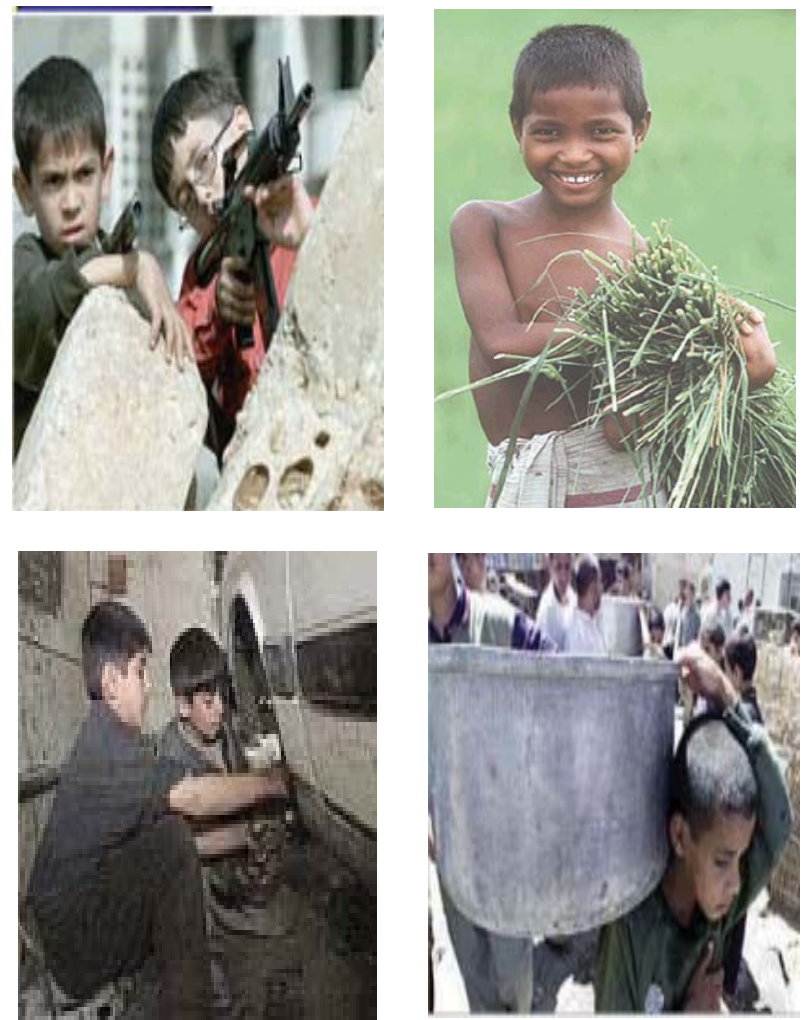

Figure7: Some aspects of exploitation of children in works and war

\section{Conclusion}

Behavioral Geography is important new themes in human geography examines human behavior using a disaggregate approach, deals with the study of cognitive processes with its response to the environment, through behaviorism. This paper aims to study another dimensions in behavioral geography related to medical geography branch as a subfield in geographic discipline. Environmental health and human diseases is in the focus of this study, through many aspects like utilization building roofs in multi unhealthy using. Nutrition behavior. Treatment behavior, Health awareness. Child abuse also is in the focus of this study too because it has relation to ethics and to determine areal differentiations between many regions and laws control these phenomena.

\section{References}

Glass, J.E. (2007). Behavior analytic grounding of sociological social constructionism The Behavior Analyst Today, 8 (4), 426-433

Elsabawy,M.N., Geographical dimensions in sickle cell Anemia : a study in Medical geography, Egyptian Geographical Society Bulletin, 2002.

Child Abuse: Behavioral Geographic study, Minia University bookstore, I.S.B.N : 977-17-0995-x, 2003.

Behavioral dimension in the study of Medical Geography, with applied study in the Egyptian Village "toukh Elkhail" province Mina, Egyptian Geographical Society Bulletin, 2004. 
"Contributions of Geographers in the field of medical geography from the middle of twentieth century", faculty of Arts of Alexandria University Bulletin, Damanhur Branch, 2003.

-- "Unhealthy Using of buildings roofs : An Ecological applied study", Geography Department conference in Alexandria University, July 2006.

--"Geographical and health dimensions for women working in city markets": in women health conference, Assuit University Egypt, April 2007.

"Toward Healthy strategic to protect reclamation lands from Endemic diseases", Geography Department conference in Alexandria University, July 2007.

--- Directions of Medical geography studies in Egypt : a new Perspective, paper in 31st international Geographical Congress, Tunis 2008.

--- "International Nutritional Gap and its effects in Egypt and world", in Population and Nutritional resources in Egypt conference, 27 April 2009 under auspice of higher Cultural convention: geography committee,

- "Environmental health Awareness Scale :A proposed model for Egypt as a developing country", Journal of Egyptian Society for environmental Changes, Volume 3 Number.1, 2011.

--"Geography of Medicinal and aromatic crops in Egypt", A study in medical geography, Mediterranean center of social and educational research, vol 2 no 9, 2012.

Norton, W. (1997). Human geography and behavior analysis: An application of behavior analysis to the evolution of human landscapes. The Psychological Record, 47, 439-460.

Norton, W. (2001). Initiating an affair human geography and behavior analysis. The Behavior Analyst Today, 2 (4), 283290

Norton, W. (2002) Explaining Landscape Change: Group Identity and Behavior. The Behavior Analyst Today, 3 (2), 155160. 
